\title{
Edible candelilla wax coating with fermented extract of tarbush improves the shelf life and quality of apples
}

\author{
Miguel A. De León-Zapata ${ }^{a}$, Aide Sáenz-Galindo ${ }^{a}$, Romeo Rojas-Molina ${ }^{a}$, \\ Raúl Rodríguez-Herrera ${ }^{a}$, Diana Jasso-Cantú ${ }^{b}$, Cristóbal N. Aguilar ${ }^{a, *}$ \\ a Department of Research (DIA-UAdeC), School of Chemistry, Universidad Autónoma de Coahuila, Saltillo 25280, \\ Coahuila, Mexico \\ ${ }^{\mathrm{b}}$ Laboratory of Phytochemistry, Plant Breeding Department, Universidad Autónoma Agraria Antonio Narro, \\ Buenvista, Saltillo 25000, Coahuila, Mexico
}

\section{A R T I C L E I N F O}

\section{Article history:}

Received 27 April 2014

Received in revised form

27 December 2014

Accepted 6 January 2015

Available online 17 January 2015

Keywords:

Candelilla wax

Fermented extract

Tarbush

Edible coating

Apple

\begin{abstract}
A B S T R A C T
Edible coating formulated with candelilla wax and fermented extract of tarbush was applied for immersion to evaluate its effects on the shelf life and quality of Golden delicious apples in marketing conditions stored at room temperature $\left(27 \pm 1^{\circ} \mathrm{C}\right)$. Control treatments were apples without edible coating. Changes in appearance, weight loss, water activity and firmness were monitored during 8 weeks. A sensory evaluation of preference in taste and appearance was performed in the apples. Edible coatings were able to reduce significantly the change in appearance, weight loss, water activity and firmness $(p \leq 0.05)$ in the apples. Results of the sensory evaluation demonstrated edible coating with fermented extract of tarbush did not alter appearance and taste of apples. According to the results, fermented extract of tarbush incorporated into the edible coating appear to be a promising preservation alternative and effective method improve the quality and shelf life of apples in marketing conditions.
\end{abstract}

(C) 2015 Elsevier Ltd. All rights reserved.

\section{Introduction}

There is currently a high demand for healthier and more natural foods for human consumption. This has led to development of natural technologies for food conservation. In recent years, research has focusing on search of naturally occurring substances capable of acting as alternative antimicrobials and antioxidants in minimally processed fruits and vegetables (Saucedo-Pompa et al., 2009), in order to reduce the negative effects of maturation process, improving quality of foodstuffs, and impacting positively on food quality (SaucedoPompa et al., 2007).

A natural alternative to extend shelf life of these products during storage is the use of edible coatings, which is defined as a cover material that is applied to edible food to improve appearance, being an effective barrier to transmission of gases, solving problems of migration of moisture, oxygen, carbon dioxide and aromas (Cuq, Gontard, \& Guilbert, 1995; Fernández-Álvarez, 2000), reducing maturation process, prolonging life and quality of a vegetable or fruit (Vernon, Pez, \& Garc, 1999).

\footnotetext{
* Corresponding author. Tel.: +52 844416 1238; fax: +52 8444159534 .

E-mail address: cristobal.aguilar@uadec.edu.mx (C.N. Aguilar).

http://dx.doi.org/10.1016/j.fpsl.2015.01.001

2214-2894/C 2015 Elsevier Ltd. All rights reserved.
} 
Tarbush (Flourensia cernua) plant is widely distributed in the semiarid region of Northern Mexico and Southern United States of Amerca, which is currently only used empirically for infusions preparation to treat some diseases or ailments for the rural population in Mexico, particularly (Belmares, Garza, Rodríuez, Contreras-Esquivel, \& Aguilar, 2009). Tarbush extracts or constituents have reported to possess antioxidant (Abou-Gazar, Bedir, Takamatsu, Ferreira, \& Khan, 2004), antiHIV (Gnabre, Ito, Ma, \& Huang, 1996), antimicrobial, enzyme inhibitory, antitumor (MacRae \& Towers, 1984), and antihyperglycemic (Luo et al., 1998) activities. Tarbush leaves contain substantial levels of polyphenolic compounds (Hyder, Fredrickson, Estell, Lucero, \& Remmenga, 2005), which may have digestive properties (Belmares et al., 2009) and fungicide activity against phytopathogenic fungi such as Rhizoctonia solani, Phytophthora infestans (Gamboa-Alvarado, HernándezCastillo, Guerrero-Rodríguez, Sánchez-Arizpe, \& Lira-Saldivar, 2003), and Colletotrichum spp. (Tellez et al., 2001).

Polyphenols, particularly tannins are secondary metabolites present in different plants such as tarbush (Ventura et al., 2008) and act as a defense against animal and microbial attack (Belmares et al., 2009). It is important to note that the tannins are generally considered as inhibitors of microorganisms growth (Belmares et al., 2009).

Most phenolic compounds found in plants, as tarbush, are conjugated with sugars (mainly glucose) forming glycosides (De León et al., 2013). This combination reduces their ability to function, since the availability of the free hydroxyl groups in phenolic rings is diminished (Vattem \& Shetty, 2003). That is why in this work was performed a tarbush fungal fermentation to remove the sugars and release the phenolic compounds catechin equivalents.

At the present time, the possibility of producing phenolic antioxidant present in tannins-rich bushes, such as tarbush mainly derivatives of biodegradation of the leaves, by fermentation processes, are a reality (Ventura et al., 2008). Plants can be used as substrate to produce powerful antioxidants by microbiological methods through fermentation (Belmares-Cerda, Reyes-Vega, Contreras-Esquivel, Rodríguez-Herrera, \& Aguilar, 2003).

The high tannin content of tarbush and the ability to be biologically degraded such compounds by solid state fermentation procedures, shows the potential value-added use of this plant material for recovery of fine chemicals such as monomeric antioxidants, such as gallic acid (Belmares et al., 2009).

The amount of aflatoxin present in the fermented plant material of tarbush (AF B1 409-612 ppt) as consequence of fungal growth was minimal considering the maximum permitted levels in food established in NOM-188-SSA1-2002 (300 mg/kg) and in the NOM-021-PSC-94 (20 ppb for AF B1), therefore these quantities fail to cause toxic effects in humans (Mercado-Martinez, 2006).

Waxes are effective in blocking the migration of moisture, being candelilla wax the most resistant one in comparation with carnauba wax and beeswax (Bósquez-Molina \& VernonCarter, 2005). Candelilla E. antisyphilitica Zucc. is an endemic specie of the semiarid regions of the borderline between Mexico and USA; from this plant is obtained a wax, which is a substance generally recognized as safe (GRAS) by the Food and Drug Administration (FDA) (Saucedo-Pompa et al., 2009).
In Mexico, apple Golden delicious is one of the most important temperate fruits. The national production of Golden delicious apples is of 375,055 t per year and in the state of Coahuila produces approximately one tenth of national production (SIAP, 2012). The producer region is located in the Sierra of Arteaga mainly in locations like Carbonera, Los Lirios, El Tunal, Jamé, San Antonio of Alazanas and Huachichil (Zermeño-Gonzáles et al., 2008).

However, apple Golden delicious production is strongly affected by poor post-harvest management, presence of pests, particularly fungal pathogens and its short shelf life because it is a perishable climacteric type fruit, which means that even under refrigerated conditions, this fruit may be decomposed (Guerrero-Prieto et al., 2004).

The main objective of this work was to evaluate the effects of a candelilla wax based edible coating formulated with fermented extract of tarbush as a natural source of antioxidants on the shelf life and quality of apples Golden delicious in marketing conditions.

\section{Materials and methods}

\subsection{Raw materials}

Tarbush plant was provided by Fitokimica Mexicana S.A. de C.V. (Saltillo, México). Plant material was dehydrated in an oven at $60 \pm 1{ }^{\circ} \mathrm{C}$ for $48 \mathrm{~h}$. Plant leaves were separated from stems, and pulverized in a miller. Powdered plant was stored in black plastic bags for later use. Refined candelilla wax was provided by Bioingenio Lifetech S.A. de C.V. (Saltillo, México). Arabic gum and jojoba oil were purchased in the local Market of Raw Materials in the Saltillo City, México).

Apples Golden delicious were purchased in the month of October (2011) from the central market in the City of Saltillo, Mexico. These fruits were produced in Arteaga Coahuila. The fruit selection criteria were: similar size, absence of skin damage, apparent absence of microorganisms, maturity and color. Fruits were sorted into completely randomized groups.

\subsection{Solid state fermentation (SSF) of tarbush leaves}

The strain of Aspergillus niger GH1 (DIA-UAdeC collection) was utilized for SSF of tarbush. Fungal spores were propagated in $250 \mathrm{ml}$ Erlenmeyer flasks containing sterile potato dextrose agar and incubated at $30 \pm 1^{\circ} \mathrm{C}$ for 5 days. SSF was carried out in tray reactors as follows: $50 \mathrm{~g}$ of powdered and dried plant were placed into each reactor. Then, moisture content was adjusted at $60 \mathrm{~g} / 100 \mathrm{~g}$ with Czapek-Dox broth at an initial pH of 5.5 and inoculated with $2 \times 10^{7} \mathrm{~A}$. niger spores per gram of dehydrated plant. Finally, reactors were incubated at $30 \pm 1{ }^{\circ} \mathrm{C}$ for $12 \mathrm{~h}$. Samples were dehydrated in an oven at $60 \pm 1{ }^{\circ} \mathrm{C}$ for $24 \mathrm{~h}$.

\subsection{Preparation of the aqueous extract}

About $50 \mathrm{~g}$ of fermented tarbush were homogenized in $500 \mathrm{ml}$ of deionized water. This mixture was stirred vigorously for $60 \mathrm{~s}$, then centrifuged for $20 \mathrm{~min}$ at $1500 \times \mathrm{g}$, supernatant was filtered, using Whatman filter paper No. 1. The filtrate was stored in plastic containers at $4 \pm 1{ }^{\circ} \mathrm{C}$ and protected from 
light. The aqueous extract from fermented tarbush was lyophilized.

\subsection{Formulation and application of the edible coatings}

Edible coatings were prepared according the procedure reported by Saucedo-Pompa et al. (2007). For emulsification, arabic gum was homogenized using a homogenizer (International TM Mod. Ll-17 V) in distilled water at room temperature $\left(27 \pm 1^{\circ} \mathrm{C}\right)$ and then heated to $80 \pm 1^{\circ} \mathrm{C}$. The candelilla wax and jojoba oil were added and homogenized all components at $15,000 \mathrm{rpm}$ for $15 \mathrm{~min}$. Fermented extract of tarbush was added at $500 \mathrm{ppm}$ in the edible coating, based on a previous work reported by De León et al. (2013).

Edible coatings were prepared in two formulations named as follows: AWCE, edible coating with fermented extract of tarbush and AWC, edible coating without fermented extract. Controls were apples without edible coating AWOC. The apples were washed and disinfected with a chlorine solution $(500 \mathrm{ppm})$ for $5 \mathrm{~min}$ and dried in one room with room temperature $\left(27 \pm 1^{\circ} \mathrm{C}\right)$ registered with a thermometer. The apples were dipped in the edible coating for $2 \mathrm{~s}$ and then dried using a fan at room temperature $\left(27 \pm 1^{\circ} \mathrm{C}\right)$ registered with thermometer for $2 \mathrm{~min}$.

\subsection{Evaluation of fruit during the storage}

The apples were stored in marketing conditions at room temperature $\left(27 \pm 1^{\circ} \mathrm{C}\right)$. Experiment was evaluated with four replicates per sampling. In order to evaluate the shelf life of fruit and the functionality of edible coating, several parameter of quality were measured each week during a storage period of 8 weeks. These parameters were: loss of weight, with the help of an analytical balance Ohaus Model E-02130 (Parsippany, USA). Fruit appearance using a digital camera Panasonic DMCLZ2. Loss of firmness using a universal penetrometer model Humboldt H-1200 (Chicago, USA) and water activity (aW) using an Aqualab Series 3 device (Decagon, USA) at room temperature $\left(27 \pm 1^{\circ} \mathrm{C}\right)$.

\subsection{Sensory evaluation}

The sensory evaluation was performed after applied treatments AWC and AWCE with the finality of knowing if the applications of the coatings change the appearance (considering the homogeneity of the coating, the presence of cracks or spots) and taste of apples in comparison with control apples AWOC. Panel of evaluation was integrated by 104 untrained panelists (males 63, females 41, age 20-24). Panelists were asked to rank the samples according their preference in appearance and taste of the fruit (1 for the most preferred and 3 for the least preferred) in an answer sheet previously provided. Data were analyzed using a Kramer's multiple comparison tests as modified by Joanes (1985). It was used a significance level of $5 \%$ for statistical tests.

\subsection{Experimental design and data analysis}

Experiments were established under a complete randomized block design. Analysis of variance and the Tukey multiple range test for means comparison were used to analyze the data.

\section{Results and discussion}

In all treatments, fruit weight loss increased during the storage period (Fig. 1). Apples with AWCE resulted with lower weight loss (20 g/100 g) however there was not significantly difference $(p \leq 0.05)$ with respect to apples with AWC (27 g/100 g) (Fig. 1). The highest loss of weight was found in control apples AWOC (37 g/100 g) from the 5th week (Fig. 1). The weight loss occurs because after the fruit harvest it has a natural tendency for weight loss, mainly by transpiration process (Krochta \& De Mulder-Johnston, 1997). It has been shown that the use of lipids as coatings decreases loss of humidity (Kester \& Fenema, 1986) in fruits as papayas (Guilbert, 1988), apples (Assis \& Pessoa, 2004), mangoes (Hoa \& Marie Noelle, 2008), green bell peppers (Beaulieu, Park, Ballew Mims, \& Kuk, 2009) and lemons (Bisen, Pandey, \& Patel, 2012).

The results of weight loss (Fig. 1) are related to the firmness and water activity of fruits because at the end of the storage period the apples coated with AWCE $(p \leq 0.05)$ maintain the initial values of firmness $(205-271 \mathrm{~mm} / 10)$ (Fig. 2) and aW (0.98-0.97 at $27 \pm 1^{\circ} \mathrm{C}$ ) (Fig. 3) compared to apples coated with AWC and control apples AWOC, because the weight loss during transpiration of apples by the lack of a protective barrier (Fig. 1). This is attributed to reduction of open area of the emulsified solids network, which restricts transport of water vapor from the inside (Baez et al., 2001) by closure of the stomata, reducing transpiration and microbial activity (Bisen et al., 2012).

The results were evident when observed the appearance of the fruits after storage period ( 8 weeks). Because edible coatings (AWC and AWCE) affect the appearance in a minor level compared to control apples (Fig. 4). However apples coated with AWCE showed better appearance compared to apples coated with AWC (Fig. 4).

The use of fermented extract of tarbush as one part of edible coating of candelilla wax decreases in greater proportion the weight loss, maintained the firmness and aW in fruits

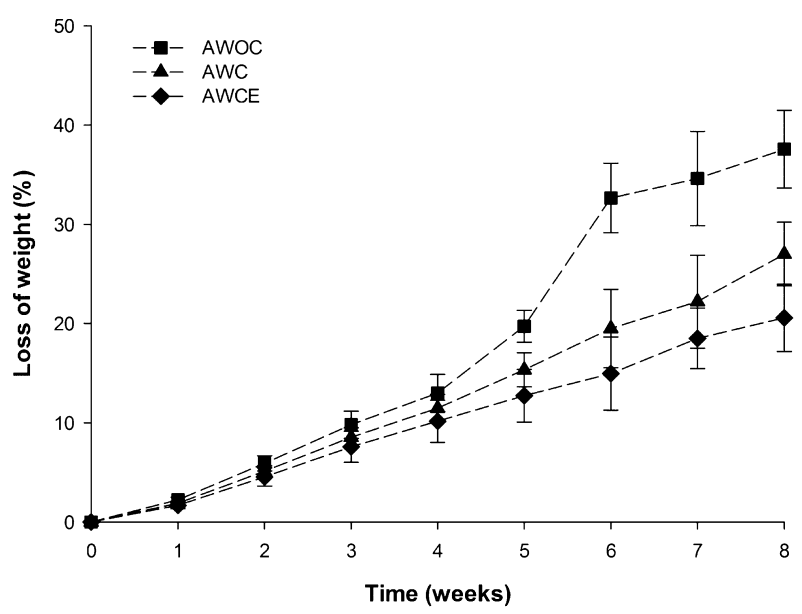

Fig. 1 - Effect of edible coating on the loss of weight of apples with AWOC (ם), AWC (A) and AWCE ( $\bullet)$. 


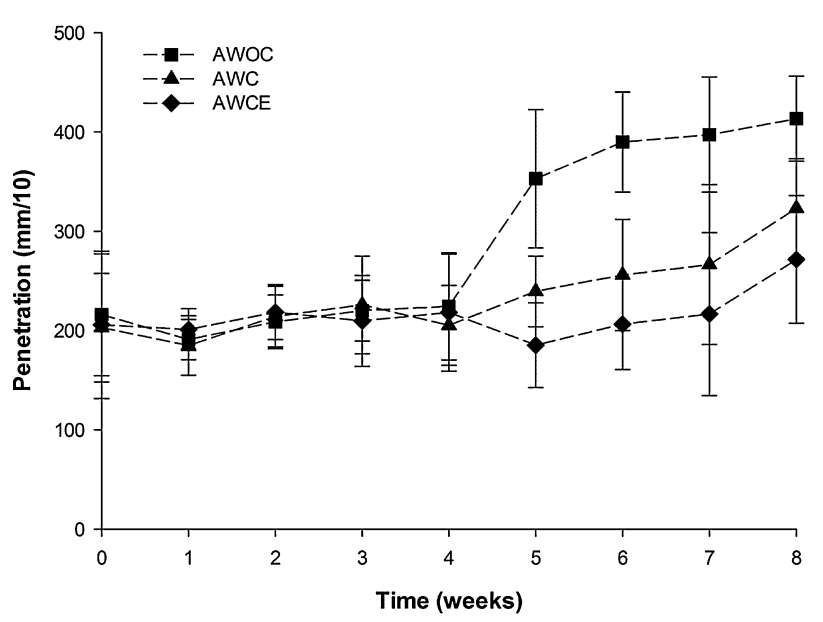

Fig. 2 - Effect of edible coating on firmness of apples with AWOC ( $\square)$, AWC $(\Delta)$ and AWCE $(\diamond)$.

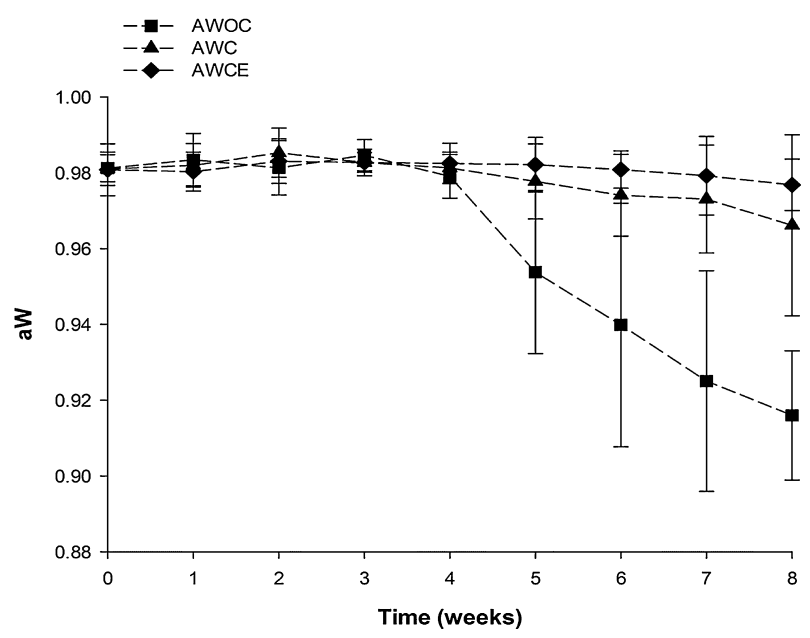

Fig. 3 - aW of apples with AWOC ( $\square$ ), AWC ( $A$ ) and AWCE $(\diamond)$.

that an edible coating of candelilla wax alone. De León et al. (2013) reported that the fermented extract of tarbush used in this work contains from 0.3 to $0.35 \mathrm{mg}$ of phenolic compounds catechin equivalents per gram of plant, in addition to have antioxidant activity (60-65\%) and antifungal against Fusarium oxysporum and Penicillium expansum. It is possible that the phenolic compounds released during fungal fermentation of tarbush interact by hydrogen bonds with each of the chemical
Table 1 - Preference results performed by the means obtained from each treatment of Golden delicious apples.

\begin{tabular}{lccccccc} 
Treatment & \multicolumn{3}{c}{ Taste } & & \multicolumn{3}{c}{ Appearance } \\
\cline { 2 - 4 } \cline { 6 - 8 } & Male & Female & Total & & Male & Female & Total \\
\hline AWOC & $2.0^{\mathrm{a}}$ & $2.0^{\mathrm{a}}$ & $2.0^{\mathrm{a}}$ & & $2.1^{\mathrm{a}}$ & $2.5^{\mathrm{a}}$ & $2.3^{\mathrm{a}}$ \\
AWC & $2.1^{\mathrm{a}}$ & $2.0^{\mathrm{a}}$ & $2.1^{\mathrm{a}}$ & & $2.0^{\mathrm{a}}$ & $1.8^{\mathrm{b}}$ & $1.8^{\mathrm{b}}$ \\
AWCE & $1.7^{\mathrm{a}}$ & $1.9^{\mathrm{a}}$ & $1.8^{\mathrm{a}}$ & & $1.8^{\mathrm{a}}$ & $1.6^{\mathrm{b}}$ & $1.7^{\mathrm{b}}$ \\
\hline
\end{tabular}

${ }^{a, b}$ Values with different letters differ significantly $(p \leq 0.05)$ in the same column.

structures of the components of edible coating, mainly polysaccharide chains and proteins contained in gum arabic (Pasquel, 2001) because to the ability of the hydroxyl groups of the phenolic compounds of tarbush to form complexes with polysaccharides and proteins (Aguilar et al., 2007) and thereby create a more closed structure than that formed on the edible coating without extract of tarbush.

Ochoa-Reyes et al. (2013) reported that an edible coating of candelilla wax with extract of tarbush prevents further weight loss, improve firmness and the appearance of green bell peppers that edible coating alone. Similar results have been reported on the application of edible coatings based waxes with other natural active compounds as ellagic acid in apples, bananas and avocados (Saucedo-Pompa et al., 2007, 2009; Ochoa et al., 2011), extract of propolis in papayas (BarreraBello, Gil-Loaiza, García-Pajón, Durango-Restrepo, \& GilGonzález, 2012) and lemon essential oil in apples (Wan-Shin, Hye-Yeon, Nak-Bum, Ji-Hyun, \& Kyung-Bin, 2014).

Results of sensorial evaluation demonstrated that in the male preference it was found that there was no significant difference $(p \leq 0.05)$ in the appearance of apples coated with AWC, AWCE and control apples AWOC (Table 1). On the other hand, the female preference showed significant differences $(p \leq 0.05)$ in the appearance of control apples AWOC and apples coated with AWCE and AWC (Table 1). There were no significant differences $(p \leq 0.05)$ between untrained panelists (males and females) in the results of the preference of fruit taste. It was found that the presence of edible coating with fermented extract of tarbush AWCE did not alter the appearance and taste of apples.

\section{Conclusions}

Application of candelilla wax-based edible coating with fermented extract of tarbush as natural antioxidants source

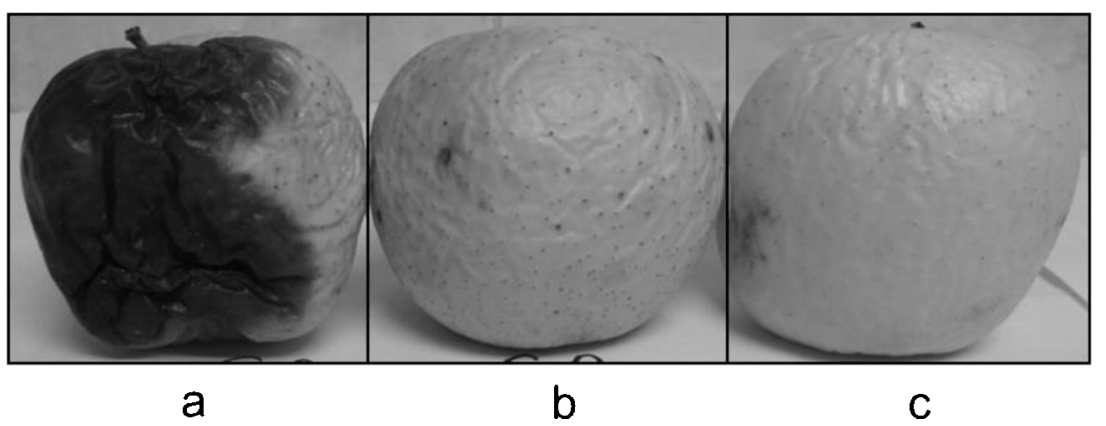

Fig. 4 - Appearance changes in treatments AWOC (a), AWC (b) and AWCE (c) after 8 weeks of storage. 
resulted in a positive effect reducing the weight loss and maintain the water activity and the firmness improving significantly the quality and shelf life of apples Golden delicious for 8 weeks in marketing conditions. This edible coating did not alter appearance and taste of apples in the sensory evaluation. Even the application of edible coating AWC improves the shelf life and quality of apples. This work is an initial effort for the use of phenolic compounds derived from tannin biodegradation during the fungal solid-state fermentation of tarbush leaves as an alternative to increase the value and use of these plants widely distributed in semiarid regions of Mexico.

\section{Acknowledgments}

Authors thank National Council of Science and Technology (CONACYT) of Mexico for the financial support through the research project CONAFOR-CONACYT-S0002-2008-C01-91 633. Author M.A. De Leon thanks CONACYT for the scholarship received for his Master Program in Food Science and Technology at the Universidad Autónoma de Coahuila.

\section{R E F E R E N C E S}

Abou-Gazar, H., Bedir, E., Takamatsu, S., Ferreira, D., \& Khan, I. A. (2004). Antioxidant lignans from Larrea tridentata. Phytochemistry, 65, 2499-2505.

Aguilar, C. N., Rodríguez, R., Gutiérrez-Sánchez, G., Augur, C., Favela-Torres, E., Prado-Barragan, L. A., et al. (2007). Microbial tannases: Advances and perspectives. Applied Microbiology and Biotechnology, 76, 47-59.

Assis, O., \& Pessoa, J. (2004). Preparation of thin films of chitosan for use as edible coatings to inhibit fungal growth on sliced fruits. Brazilian Journal of Food Science, 7(1), 17-22.

Baez, R., Bringas, E., González, G., Mendoza, T., Ojeda, J., \& Mercado, J. (2001). Comportamiento postcosecha del mango 'Tommy Atkins' tratado con agua caliente y ceras. Proceedings of the Interamerican Society for Tropical Horticulture, 44, 39-43.

Barrera-Bello, E., Gil-Loaiza, M., García-Pajón, C. M., DurangoRestrepo, D. L., \& Gil-González, J. H. (2012). Use of a coating formulated with propolis for postharvest handling of papaya (Carica papaya L. cv. Hawaiian) fruits. Revista Facultad Nacional de Agronomía, 65(1), 6497-6506.

Belmares-Cerda, R., Reyes-Vega, M. L., Contreras-Esquivel, J. C., Rodríguez-Herrera, R., \& Aguilar, C. N. (2003). Efecto de la fuente de carbono sobre la producción de tanasa en dos cepas de Aspergillus niger. Revista Mexicana de Ingeniería Química, 2(2), 95-100.

Belmares, R., Garza, Y., Rodríuez, R., Contreras-Esquivel, J. C., \& Aguilar, C. N. (2009). Composition and fungal degradation of tannins present in semiarid plants. Electronic Journal of Environmental, Agricultural and Food Chemistry, 8(4), 312-318.

Beaulieu, J. C., Park, H. S., Ballew Mims, A. G., \& Kuk, M. S. (2009). Extension of green bell pepper shelf life using oilseedderived lipid films from soapstock. Industrial Crops and Products, 30, 271-275.

Bisen, A., Pandey, S. K., \& Patel, N. (2012). Effect of skin coating on prolonging shelf life of kagzi lime fruits (Citrus aurantifolia Swingle). Journal of Food Science and Technology, 49, 753-759.
Bósquez-Molina, E., \& Vernon-Carter, E. J. (2005). Efecto de plastificantes y calcio en la permeabilidad al vapor de agua de películas a base de goma de mezquite y cera de candelilla. Revista Mexicana de Ingeniería Química, 4(2), 157-162.

Cuq, B., Gontard, N., \& Guilbert, S. (1995). Edible films and coatings as active layers. In M. L. Rooney (Ed.), Active Food Packaging (pp. 111-135). London, U.K Springer-Verlag.

De León, M. A., Saenz, A., Jasso-Cantu, D., Rodríguez, R., Pandey, A., \& Aguilar, C. N. (2013). Fermented Flourensia cernua extracts and their in vitro assay against Penicillium expansum and Fusarium oxysporum. Food Technology and Biotechnology, 51(2), 233-239.

Fernández-Álvarez, M. (2000). Active food packaging. Food Science and Technology International, 6(2), 97-108.

Gamboa-Alvarado, R., Hernández-Castillo, F. D., GuerreroRodríguez, E., Sánchez-Arizpe, A., \& Lira-Saldivar, R. H. (2003). Inhibición del crecimiento micelial de Rhizoctonia solani Kuhn y Phytophtora infestans Mont. (De Bary) con extractos vegetales metanólicos de hojasén (Flourensia cernua D.C.), Mejorana (Origanum majorana L.) y trompetilla (Bouvardia ternifolia (Ca.)). Revista Mexicana de Fitopatología, 21, 13-18.

Gnabre, J. N., Ito, Y., Ma, Y., \& Huang, R. C. (1996). Isolation of anti-HIV-1 lignans from Larrea tridentata by counter-current chromatography. Journal of Chromatography A, 719, 353-364.

Guerrero-Prieto, V. M., Trevizo-Enriquez, M. G., Gardea-Béjar, A. A., Figueroa-Valenzuela, C., Romo-Chacón, A., BlancoPérez, A. C., et al. (2004). Identificación de levaduras epifitas obtenidas de manzana (Malus syluestris (L.) Mill. Var. Domestica (Borkh.) Mansf.) para el control biológico poscosecha. Revista Mexicana de Fitopatología, 22(2), 223-230.

Guilbert, S. (1988). Use of superficial edible layer to protect intermediate moisture foods application to the protect of tropical fruit dehydrated by osmosis. In C. C. Seow (Ed.), Food Preservation by Moisture Control (pp. 119-219). Londres, Reino Unido: Elsevier.

Hoa, T. T., \& Marie Noelle, D. (2008). Effects of different coatings on biochemical changes of "cat hoa loc" mangoes in storage. Postharvest Biology and Technology, 48, 150-152.

Hyder, P. W., Fredrickson, E. L., Estell, R. E., Lucero, M. E., \& Remmenga, M. D. (2005). Loss of phenolic compounds from leaf litter of creosotebush (Larrea tridentata (Sess. \& Moc. Ex D.C.) Cov.) and tar bush (Flourensia cernua D.C.). Journal of Arid Environments, 61, 79-91.

Joanes, D. N. (1985). On a rank sum test due to kramer. Journal of Food Science, 50(5), 1442-1444.

Kester, J., \& Fenema, O. (1986). Edible films and coatings: A review. Food Technology, 40(1), 47-59.

Krochta, J. M., \& De Mulder-Johnston, C. (1997). Edible and biodegradable polymer films: Challenges and opportunities. Food Technology, 51(2), 61-74.

Luo, J., Chuang, T., Cheung, J., Quan, J., Tsai, J., Sullivan, C., et al. (1998). Masoprocol (nordihydroguiaretic acid): A new antihyperglycemic agent isolated from the creosote bush (Larrea tridentata). European Journal of Pharmacology, 346, 77-79.

MacRae, W. D., \& Towers, G. H. N. (1984). Biological activities of lignans. Phytochemistry, 23, 1207-1220.

Mercado-Martinez, D. (2006). Cambios en el contenido de polifenoles presentes en plantas del semidesierto mexicano utilizando cepas de Aspergillus niger y su evaluación In Vitro como posible alimento para el ganado.. (Thesis) México: Universidad Autónoma de Coahuila.

Ochoa, E., Saucedo-Pompa, S., Rojas-Molina, R., De La Garza, H., Charles-Rodríuez, A. V., \& Aguilar, C. N. (2011). Evaluation of a candelilla wax-based edible coating to prolong the shelflife quality and safety of apples. American Journal of Agriculture and Biological Science, 6, 92-98.

Ochoa-Reyes, E., Martínez-Vazquez, G., Saucedo-Pompa, S., Montañez, J., Rojas-Molina, R., De León-Zapata, M. A., et al. 
(2013). Improvement of shelf life quality of green bell peppers using edible coating formulations. Journal of Microbiology, Biotechnology and Food Sciences, 2(6), 2448-2451.

Pasquel, A. (2001). Gomas: Una aproximación a la industrial de los alimentos. Revista Amazónica de Investigación Alimentaria, 1(1), 1-8.

Saucedo-Pompa, S., Jasso-Cantu, D., Ventura-Sobrevilla, J., Sáenz-Galindo, A., Rodríguez-Herrera, R., \& Aguilar, C. N. (2007). Effect of candelilla wax with natural antioxidants on the shelf life quality of fresh-cut fruits. Journal of Food Quality, 30(5), 823-836.

Saucedo-Pompa, S., Rojas-Molina, R., Aguilera-Carbó, A. F., SáenzGalindo, A., Garza, H. L., Jasso-Cantú, D., et al. (2009). Edible film based on candelilla wax to improve the shelf life and quality of avocado. Food Research International, 42(4), 511-515.

SIAP. (2012). http://www.siap.gob.mx/. http://www.siap.gob.mx/ cierre-de-la-produccion-agricola-por-estado/. Accessed 17.08.14.

Tellez, M., Estell, R. E., Fredrickson, E. L., Powell, J., Wedge, D., Schrader, K., et al. (2001). Extracts of Flourensia cernua (L): volatile constituents and antifungal, antialgal, and antitermite bioactives. Journal of Chemical Ecology, 27, 2263-2285.
Vattem, D. A., \& Shetty, K. (2003). Ellagic acid production and phenolic antioxidant activity in cranberry pomace (Vaccinium macrocarpon) mediated by Lentinus edodes using a solid-state system. Process Biochemistry, 39, 367-379.

Ventura, J., Belmares-Cerda, R., Aguilera-Carbó, A., ContrerasEsquivel, J. C., Rodríuez-Herrera, R., \& Aguilar, C. N. (2008). Fungal biodegradation of tannins from creosote bush (Larrea tridentata Cov.) and tar bush (Fluorensia cernua) for gallic and ellagic acids production. Food Technology and Biotechnology, 46, 213-217.

Vernon, E. J., Pez, L. J., \& Garc, H. S. (1999). Uso de recubrimientos biopolimericos como coadyuvantes en el tratamiento fitosanitario de mango (Mangifera indica, Variedad Manila). Revista Dintel, 7(5), 42-48.

Wan-Shin, J., Hye-Yeon, S., Nak-Bum, S., Ji-Hyun, L., \& KyungBin, Sea-C.M.S. (2014). Quality and microbial safety of 'Fuji' apples coated with carnaubashellac wax containing lemongrass oil. LWT-Food Science and Technology, 55, 490-497.

Zermeño-Gonzáles, A., Gil-Marín, J. A., Ramírez-Rodríguez, H., Hernández-Herrera, A., Rodríguez-García, R., BenavidesMendoza, A., et al. (2008). Encalado del fruto en la producción orgánica de manzana: Impacto sobre el paño del fruto. Tropical and Subtropical Agroecosystems, 8(2), 171-179. 